\title{
Visible Light-Driven Photocatalytic Activity of Magnetic Recoverable Ternary $\mathrm{ZnFe}_{2} \mathrm{O}_{4} / \mathrm{rGO} / \mathrm{g}-\mathrm{C}_{3} \mathrm{~N}_{4}$ Nanocomposites
}

\author{
Martin Tsvetkov, ${ }^{1, *}$ Elzhana Encheva, ${ }^{1}$ Albin Pintar, ${ }^{2}$ and Maria Milanova ${ }^{1}$ \\ ${ }^{1}$ Department of Inorganic Chemistry, Faculty of Chemistry and Pharmacy, St. Kl. Ohridski University of Sofia, \\ J. Bourchier 1, 1164 Sofia, Bulgaria \\ ${ }^{2}$ Laboratory for Environmental Sciences and Engineering, National Institute of Chemistry, Hajdrihova 19, \\ 1001 Ljubljana, Slovenia \\ *Corresponding author: E-mail: mptsvetkov@gmail.com
}

Received: 01-25-2020

\begin{abstract}
$\mathrm{ZnFe}_{2} \mathrm{O}_{4} / \mathrm{rGO} / \mathrm{g}-\mathrm{C}_{3} \mathrm{~N}_{4}$ ternary nanocomposite photocatalysts with different $\mathrm{ZnFe}_{2} \mathrm{O}_{4} / \mathrm{g}-\mathrm{C}_{3} \mathrm{~N}_{4}$ weight ratio $(0.5,0.75,1)$ were prepared by a stepwise solvothermal method using ethylene glycol as the solvent. Physicochemical methods such as $\mathrm{X}$-ray diffraction, UV-Vis diffuse reflectance spectroscopy and photoluminescence spectroscopy were applied in order to characterize the composites. The formation of a meso-/macroporous structure with specific surface area between 67 and $77 \mathrm{~m}^{2} \mathrm{~g}^{-1}$ was confirmed by $\mathrm{N}_{2}$ adsorption/desorption. The bandgap of the composites was found to be lower $(2.30 \mathrm{eV})$ than that of $\mathrm{g}-\mathrm{C}_{3} \mathrm{~N}_{4}(2.7 \mathrm{eV})$. In contrast to pure $\mathrm{g}-\mathrm{C}_{3} \mathrm{~N}_{4}$, the composites showed no fluorescence, i.e. no recombination of $\mathrm{e}^{-} / \mathrm{h}^{+}$took place. All samples, including pure g- $\mathrm{C}_{3} \mathrm{~N}_{4}$ and $\mathrm{ZnFe}_{2} \mathrm{O}_{4}$, were tested for adsorption and photocatalytic degradation of aqueous malachite green model solutions $\left(10^{-5} \mathrm{M}\right)$ under visible light irradiation $(\lambda>400 \mathrm{~nm})$. The results show that the prepared nanocomposites have higher absorption and photocatalytic activity than the pristine $\mathrm{g}-\mathrm{C}_{3} \mathrm{~N}_{4}$ and $\mathrm{ZnFe}_{2} \mathrm{O}_{4}$ and can be successfully used for water purification from organic azo-dyes.
\end{abstract}

Keywords: Graphitic carbon nitride; reduced graphene oxide; zinc ferrite; photocatalysis; malachite green decomposition.

\section{Introduction}

Synthetic organic dyes are severe water pollutants causing environmental problems. They are typically aromatic compounds with structural variations, many of them resistant to degradation. ${ }^{1}$ Among them, malachite green is an organic water pollutant known to be harmful for living creatures because of its potential carcinogenicity, mutagenicity and teratogenicity in mammals. ${ }^{2}$ Depending on the polluted water composition, different methods have been applied in order to solve water contamination problems, including biological reactions, ${ }^{3}$ sedimentation, ${ }^{4-6}$ coagulation, ${ }^{7,8}$ adsorption, ${ }^{5}$ reverse osmosis, ${ }^{9,10}$ membrane filtration, ${ }^{11}$ ion exchange, ${ }^{12}$ etc. Photocatalytic processes have also been applied, and much effort has been spent on the development of different semiconductors as photocatalysts among which $\mathrm{TiO}_{2}$ and its modifications is well known. ${ }^{13-18}$

The aim of the research presented here is to develop new photocatalysts and to overcome the main limitation of $\mathrm{TiO}_{2}$, i.e. its wide band gap $(3.2 \mathrm{eV})$ that makes it active under UV light irradiation only (about $5 \%$ of sunlight). Recently the graphite analogue, graphitic carbon nitride, g- $\mathrm{C}_{3} \mathrm{~N}_{4}$, raised interest due to its unique electronic structure. It is a non-metallic polymer with n-type semiconducting behavior and unique electrical, optical, structural and physicochemical properties. Like graphite, $\mathrm{g}-\mathrm{C}_{3} \mathrm{~N}_{4}$ has a two-dimensional planar $\pi$ conjugation structure, able to enhance the electron transfer processes due to its excellent electronic conductivity. ${ }^{19}$ With its medium-sized band gap and its thermal and chemical stability in ambient environment, it has become one of the most promising photocatalytic materials. ${ }^{19}$ The interest in its application as a photocatalyst increased after its photocatalytic properties were discovered by Wang et al.. ${ }^{20}$ However, g- $\mathrm{C}_{3} \mathrm{~N}_{4}$ also has some disadvantages such as a small specific surface area, a small number of active centers, quick recombination of the photo-induced $\mathrm{e}^{-} / \mathrm{h}^{+}$, low mobility of photoinduced $\mathrm{e}^{-} /$ $\mathrm{h}^{+21}$ and an wide band gap $(2.7 \mathrm{eV}) .^{22}$ These shortcomings can be avoided by adding a co-catalyst to $\mathrm{g}-\mathrm{C}_{3} \mathrm{~N}_{4}$ to pre- 
pare nanocomposites. In recent years, particular interest has appeared in composites of $\mathrm{g}-\mathrm{C}_{3} \mathrm{~N}_{4}$ and reduced graphite oxide, rGO, due to the large specific surface area of rGO and its ability to efficiently separate photo-induced charges. ${ }^{23}$ The above effect can also be achieved by combining g- $\mathrm{C}_{3} \mathrm{~N}_{4}$ with multi-wall carbon nanotubes. ${ }^{24}$ However, these nanocomposites can only solve two of the above disadvantages of $\mathrm{g}-\mathrm{C}_{3} \mathrm{~N}_{4}$ as a photocatalyst. The wide band gap of $2.7 \mathrm{eV}$ limits the application of visible light. In order to use $\mathrm{g}-\mathrm{C}_{3} \mathrm{~N}_{4}$ as a photocatalyst with visible light, it may be combined with other semiconductor materials with a narrower forbidden zone. Due to its narrow band gap of $1.9 \mathrm{eV}$, $\mathrm{ZnFe}_{2} \mathrm{O}_{4}$ as a co-catalyst can absorb a wider range of visible light wavelengths. It may also show improved separation of photogenerated electron-hole pairs. Its magnetic properties facilitate the removal of the composites from the reaction mixture, so they can be reused. ${ }^{25}$ In the literature available, there are publications presenting studies on triple nanocomposites such as $\mathrm{CoMoS}_{2} / \mathrm{rGO} / \mathrm{C}_{3} \mathrm{~N}_{4}$ with visible light photocatalytic activity for hydrogen evolution, ${ }^{26} \mathrm{C}_{3} \mathrm{~N}_{4} /$ $\mathrm{rGO} / \mathrm{TiO}_{2}{ }^{27,28}$ for decomposition of methyl orange, rhodamine $\mathrm{B}$, and phenol under visible light, and $\mathrm{C}_{3} \mathrm{~N}_{4} /$ $\mathrm{rGO} / \mathrm{WO}_{3}$ for degradation of methylene blue. ${ }^{29}$ Both the studies mentioned and our experience with $\mathrm{ZnFe}_{2} \mathrm{O}_{4}$ as photocatalyst suggested that $\mathrm{ZnFe}_{2} \mathrm{O}_{4} / \mathrm{rGO} / \mathrm{g}-\mathrm{C}_{3} \mathrm{~N}_{4}$ would be a promising composition to study, as it potentially could overcome g- $\mathrm{C}_{3} \mathrm{~N}_{4}$ shortcomings as photocatalyst as well as take advantage of rGO for the separation of photo-induced charges. The photocatalytic properties of the nanocomposites $\mathrm{ZnFe}_{2} \mathrm{O}_{4} / \mathrm{rGO} / \mathrm{g}-\mathrm{C}_{3} \mathrm{~N}_{4}$ were tested for removal of malachite green as representative pollutant under visible light irradiation, showing better activity than the individual semiconductors. The work presented here on the preparation and the properties of $\mathrm{ZnFe}_{2} \mathrm{O}_{4} / \mathrm{rGO} / \mathrm{g}-\mathrm{C}_{3} \mathrm{~N}_{4}$ can contribute both to the knowledge of inorganic synthesis of such composites and to the improved photocatalytic removal of organic dyes from water.

\section{Experimental}

\section{1. Materials}

Chemicals such as urea (puriss. p.a., Fluka, Switzerland), graphite, $\mathrm{Zn}\left(\mathrm{NO}_{3}\right)_{2} \cdot 6 \mathrm{H}_{2} \mathrm{O}, \mathrm{Fe}\left(\mathrm{NO}_{3}\right)_{3} \cdot 9 \mathrm{H}_{2} \mathrm{O}$, and $\mathrm{CH}_{3} \mathrm{COONa} \cdot \mathrm{H}_{2} \mathrm{O}$ (all p.a., Sigma-Aldrich, USA) were used in this study.

\section{2. Synthesis of the Samples}

\section{2. 1. Synthesis of Graphitic Carbon Nitride, g- $\mathrm{C}_{3} \mathrm{~N}_{4}$}

Thermal polycondensation of urea in a closed crucible at $550{ }^{\circ} \mathrm{C}$ for $5 \mathrm{~h}$ was applied. The powder was dispersed in water and homogenized by stirring for $1 \mathrm{~h}$, followed by filtering, washing and drying at $50{ }^{\circ} \mathrm{C}$ overnight. The successful synthesis was confirmed by XRD and TEM analyses.

\section{2. 2. Synthesis of Reduced Graphene Oxide, rGO}

Graphene oxide was prepared by using the modified Hummer's method starting from graphite flakes. ${ }^{30}$ In a typical procedure, $0.5 \mathrm{~g}$ of graphite was dispersed in $50 \mathrm{~mL}$ mixture of conc. $\mathrm{H}_{2} \mathrm{SO}_{4}$ and conc. $\mathrm{H}_{3} \mathrm{PO}_{4}$ (volume ratio 9:1) and then ultrasonicated for 1 hour. After that, $6 \mathrm{~g}$ of $\mathrm{KMnO}_{4}$ was added and magnetically stirred for $5 \mathrm{~h}$ followed by $12 \mathrm{~h}$ stirring at $50^{\circ} \mathrm{C}$. The so prepared mixture was cooled to room temperature and transferred in a beaker containing $100 \mathrm{~g}$ of ice. After stirring and melting of the ice, $20 \mathrm{~mL}$ of $30 \% \mathrm{H}_{2} \mathrm{O}_{2}$ solution was added dropwise in order to remove the unreacted $\mathrm{KMnO}_{4}$. The suspension immediately changed its color from purple to yellow, indicating the formation of graphene oxide. The solid phase was separated by filtration and then dispersed in $100 \mathrm{~mL}$ of $5 \% \mathrm{HCl}$ solution in order to remove all the metal cations and then separated again by centrifugation and washing with water untill a $\mathrm{pH}=7$. The GO obtained was reduced further to rGO by hydrothermal treatment in a PTFE-lined autoclave at $180^{\circ} \mathrm{C}$ for $12 \mathrm{~h}$ using hydrazine as a reducing agent.

\section{2. 3. Synthesis of the Composites $\mathrm{ZnFe}_{2} \mathrm{O}_{4} /$ $\mathrm{rGO} / \mathrm{g}-\mathrm{C}_{3} \mathrm{~N}_{4}$}

A solvothermal method was used to prepare the composites. The metal salts $\mathrm{Zn}\left(\mathrm{NO}_{3}\right)_{2} \cdot 6 \mathrm{H}_{2} \mathrm{O}$ and $\mathrm{Fe}(-$ $\left.\mathrm{NO}_{3}\right)_{3} \cdot 9 \mathrm{H}_{2} \mathrm{O}$ were dissolved in $50 \mathrm{~mL}$ of ethylene glycol, EG, with ratio $n\left(\mathrm{Zn}^{2+}\right): n\left(\mathrm{Fe}^{3+}\right)=1: 2$. The $\mathrm{rGO}$ was added and dispersed by $30 \mathrm{~min}$ magnetic stirring and $2 \mathrm{~h}$ of sonication. After $\mathrm{g}-\mathrm{C}_{3} \mathrm{~N}_{4}$ was added, the suspension was stirred for $30 \mathrm{~min}$ by magnetic stirring, followed by $30 \mathrm{~min}$ sonication in an ultrasonic bath. After adding $3 \mathrm{~g}$ of $\mathrm{CH}_{3} \mathrm{COONa} \cdot 2 \mathrm{H}_{2} \mathrm{O}$ and stirring for $30 \mathrm{~min}$, the metal ions were precipitated. The mixture was transferred to a $75 \mathrm{~mL}$ PTFE autoclave and kept at $180{ }^{\circ} \mathrm{C}$ for $24 \mathrm{~h}$. By varying the $\mathrm{ZnFe}_{2} \mathrm{O}_{4} / \mathrm{g}_{-} \mathrm{C}_{3} \mathrm{~N}_{4}$ mass ratio $(0.5,0.75,1)$, three $\mathrm{ZnFe}_{2} \mathrm{O}_{4} / \mathrm{rGO} / \mathrm{g}-\mathrm{C}_{3} \mathrm{~N}_{4}$ composites containing 5 wt $\%$ rGO were prepared. They are mentioned further in the text as CN50 $\left(\mathrm{ZnFe}_{2} \mathrm{O}_{4}: \mathrm{g}-\mathrm{C}_{3} \mathrm{~N}_{4}=0.5\right), \mathrm{CN} 75$ $\left(\mathrm{ZnFe}_{2} \mathrm{O}_{4}: \mathrm{g}-\mathrm{C}_{3} \mathrm{~N}_{4}=0.75\right)$, and $\mathrm{CN} 100\left(\mathrm{ZnFe}_{2} \mathrm{O}_{4}: \mathrm{g}-\mathrm{C}_{3} \mathrm{~N}_{4}\right.$ $=1$ ).

\section{3. Methods for Characterization of the Samples}

$X$-Ray Diffraction to determine the crystal structure of the materials was performed using a PANalytical Empyrean $\mathrm{X}$-ray diffractometer in the $2 \theta$ range of $15-80^{\circ}$ using $\mathrm{CuKa}$ radiation $(\lambda=0.15405 \mathrm{~nm})$ for the nanocomposites and in $2 \theta$ range of $10-80^{\circ}$ for the individual components, steps of $0.01^{\circ}$ and 20 seconds exposure time at each step. The average crystallite size was calculated using the well-known Scherrer's equation. ${ }^{31}$ The microstructural information of the $\mathrm{ZnFe}_{2} \mathrm{O}_{4}$ was extracted by 
full profile Rietveld method using the FullProf Suite software. ${ }^{32} U V$-Vis absorption spectroscopy was applied using an Evolution 300 UV-Vis spectrometer (Thermo Scientific) for measuring the absorption of the samples in the range of 200-900 $\mathrm{nm}$. Bandgap energies were calculated from the UV-Vis absorption spectra in the range from 200 to $400 \mathrm{~nm}$ according to Tauc's equation $\alpha \mathrm{h} v=\mathrm{A}(h v$ $\left.-E_{g}\right)^{\mathrm{n} / 2}$, where $\mathrm{A}$ is a constant independent of $h v, E_{g}$ is the semiconductor bandgap and $\mathrm{n}$ depends on the type of transition. ${ }^{33}$ Textural characteristics such as specific surface area, total pore volume, and pore size distribution were determined at $-196^{\circ} \mathrm{C}$ using a TriStar II 3020 apparatus (Micromeritics). The total pore volume was estimated at a relative pressure $\mathrm{P} / \mathrm{P}_{0} 0.989$. Transmission electron microscopy (TEM): a JEOL JEM 2100 microscope was used at $200 \mathrm{kV}$ and up to $100 \mathrm{k}$ magnification for characterization of the morphology of the samples. Particle size distribution analysis was performed by using Image J software. ${ }^{34}$
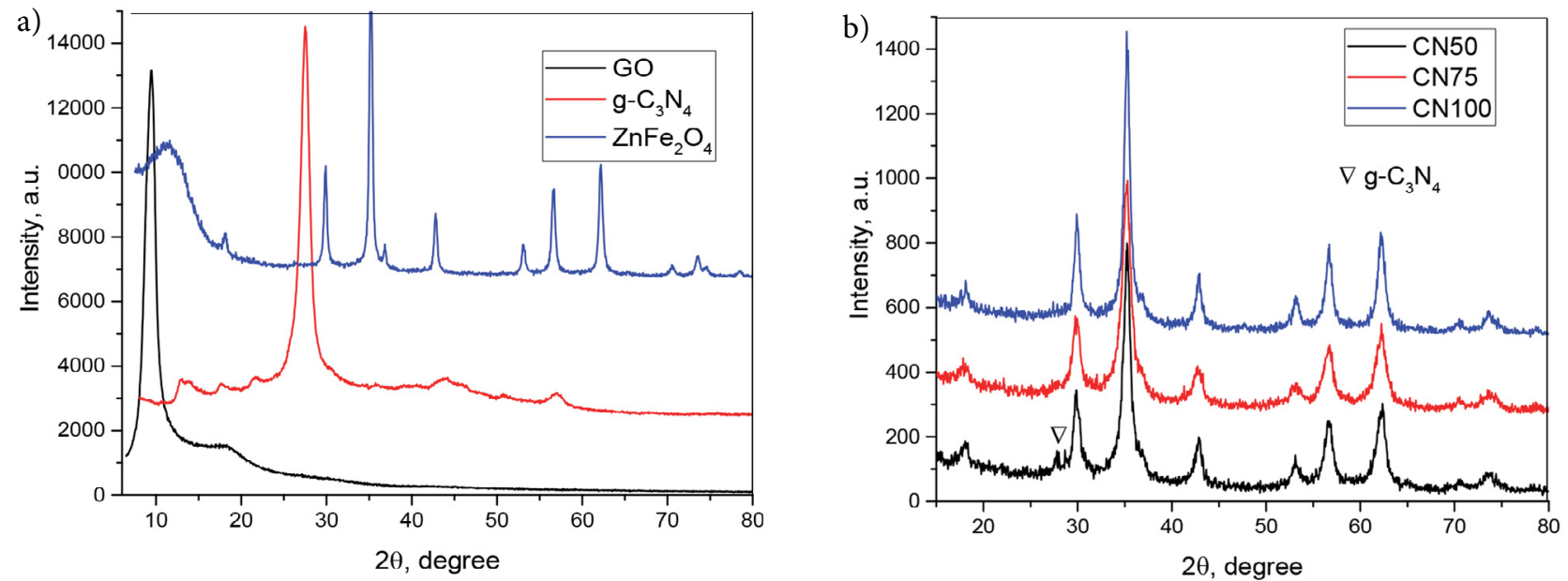

Figure 1. XRD patterns, from bottom to top (a) of the initial samples r-GO, $\mathrm{g}_{-} \mathrm{C}_{3} \mathrm{~N}_{4}, \mathrm{ZnFe}_{2} \mathrm{O}_{4}$ and (b) of the nanocomposites CN50, CN75, CN100
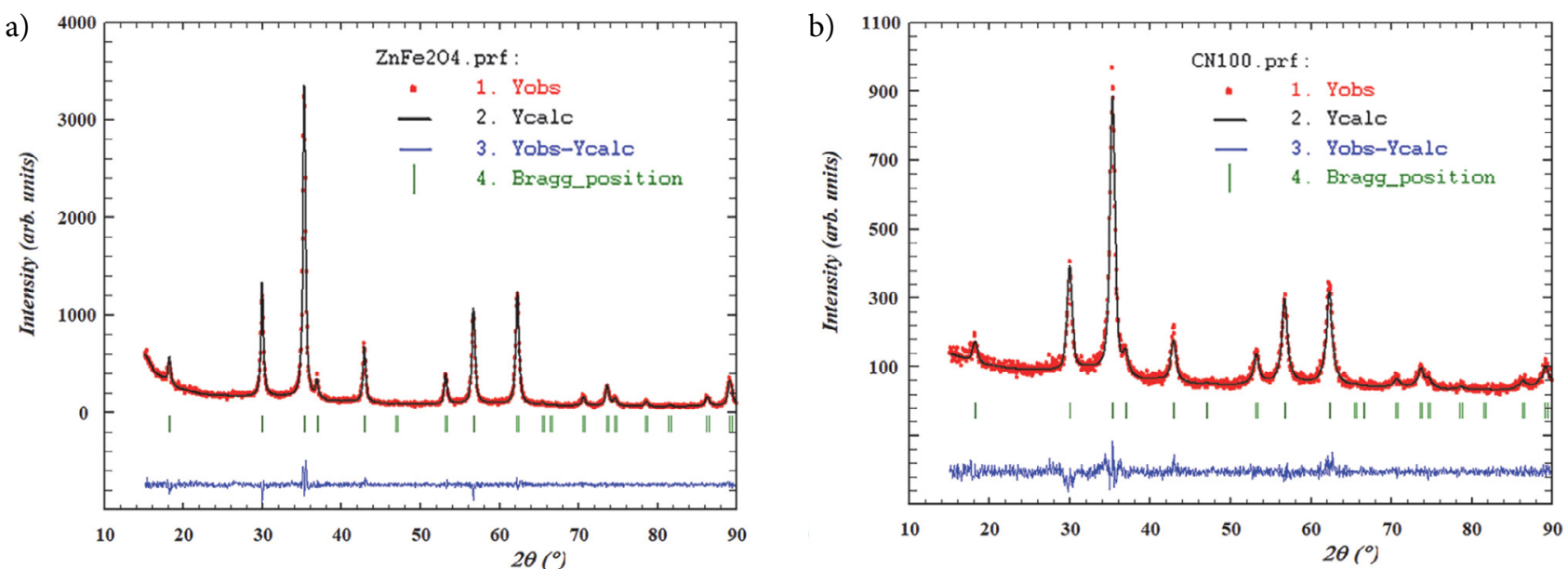

Figure 2. Experimentally observed (dots), Rietveld calculated (continuous line) and difference (continuous bottom line) profiles, obtained after Rietveld analysis of the XRD data (a) $\mathrm{ZnFe}_{2} \mathrm{O}_{4}$ and (b) the composite CN100. Peak positions are shown at the base line as small markers.

Tsvetkov et al.: Visible Light-Driven Photocatalytic Activity ... 
tion analysis. The composition of the initial substances r-GO, g- $\mathrm{C}_{3} \mathrm{~N}_{4}$ and $\mathrm{ZnFe}_{2} \mathrm{O}_{4}$ were confirmed (Fig. 1, a). The strong diffraction peak observed at $27^{\circ}$ theta in the pure g- $\mathrm{C}_{3} \mathrm{~N}_{4}$ can be assigned to the (002) diffraction plane of layered g- $\mathrm{C}_{3} \mathrm{~N}_{4}$ (JCPDS 87-1526) (Fig. 1, a). It corresponds to the characteristic interlayer stacking of aromatic segments. ${ }^{37}$ The nanocomposites mainly show the presence of $\mathrm{ZnFe}_{2} \mathrm{O}_{4}$ (Fig. 1, b). The presence of $\mathrm{g}_{-} \mathrm{C}_{3} \mathrm{~N}_{4}$ in the composites is detected below $30^{\circ} 2$ theta shown by an inversed " $\Delta$ " (Fig. 1, b).

Rietveld analysis of the XRD data of $\mathrm{ZnFe}_{2} \mathrm{O}_{4}$ and the composite $\mathrm{CN} 100$ was performed (Fig. 2, a, b). The information obtained by the Rietveld refinement was the crystallite size and microstrains as both are related (to extend) to the catalytic properties of the materials. ${ }^{38,39}$

This is also proven by the BET measurements as it can be seen later in the text (Part 3.1.3). On the other side, the microstrains are related to the density of the defects in the crystal structure. The defects, known as active centres in catalysis, are places (especially on the surface) with lower potential energy where the reaction between solid/liquid (or solid/vapor) occurs. Although this is not always true in context of photocatalysis as defects can also act as recombination centres for photogenerated $\mathrm{e}^{-} / \mathrm{h}^{+}$pairs leading to lower activity.

The lattice parameters, crystallite size, and the microstrain of the composites and the pure $\mathrm{ZnFe}_{2} \mathrm{O}_{4}$ are shown in Table 1. It can be seen that the increasing content of $\mathrm{ZnFe}_{2} \mathrm{O}_{4}$ in the composites is causing changes in all the parameters mentioned. All the values are getting closer to those of the pure $\mathrm{ZnFe}_{2} \mathrm{O}_{4}$. The microstrain is decreasing in the line 0.0177 (CN50), 0.0147(CN75), 0.0116 (CN100), and 0.0053 for the pure $\mathrm{ZnFe}_{2} \mathrm{O}_{4}$, respectively. The structure of the composites is more defective at lower zinc ferrite content. The latter can be observed in the reduction of the unit cell volume as a result of the microstrains.

\section{1. 2. Characterization of the Sample Morphology by TE}

The morphology and the structure of as-synthesized samples observed by TEM are shown in Figure 3. The layered structure of the individual $\mathrm{g}-\mathrm{C}_{3} \mathrm{~N}_{4}$ can be seen in Fig. 3 , a. The $\mathrm{ZnFe}_{2} \mathrm{O}_{4}$ particles are flower-shaped on the surface of $\mathrm{g}^{-} \mathrm{C}_{3} \mathrm{~N}_{4}$ (Fig. 3, b). The electron diffraction of the samples g- $\mathrm{C}_{3} \mathrm{~N}_{4}$ and $\mathrm{ZnFe}_{2} \mathrm{O}_{4}$ is shown in Fig. 3, c, d, respectively. It is used as supplementary analysis to the XRD and approves the successful preparation of $\mathrm{ZnFe}_{2} \mathrm{O}_{4}$ and g- $\mathrm{C}_{3} \mathrm{~N}_{4}$.

With increasing $\mathrm{ZnFe}_{2} \mathrm{O}_{4}$ content in the composites, polydispersed agglomerates are formed. The particle size distribution for CN50 is between $5-10 \mathrm{~nm}$ (Fig. 3, e), in accordance with the XRD data.

\section{1. 3. Textural Characterization}

Nitrogen adsorption - desorption isotherms measured at $-196{ }^{\circ} \mathrm{C}$ on powdered samples (Fig. 4, a) showed that the samples are of type IV, which is the typical characteristic of mesoporous materials according to the IUPAC classification. ${ }^{40}$ The isotherm of $\mathrm{ZnFe}_{2} \mathrm{O}_{4}$ with $\mathrm{H} 1$ loop is typical for well-defined cylindrical pores or agglomerates of approximately uniform spheres (Fig. 4, a). The H3 loop for the $\mathrm{g}_{-} \mathrm{C}_{3} \mathrm{~N}_{4}$ and the composites are distinctive for non-rigid aggregates of plate-like particles with slit-shaped pores. The hysteresis loops observed are characteristic of mesoporous solids and their shape exhibits a change in the pore structure. Macropores may be present as well, based on the shape of the hysteresis loops near $\mathrm{P} / \mathrm{P}_{0}=1 .^{41}$ The average pore size is rather close for the samples g- $\mathrm{C}_{3} \mathrm{~N}_{4}$, CN50 and CN75 (Table 2), while that of $\mathrm{ZnFe}_{2} \mathrm{O}_{4}$ is larger and that of $\mathrm{CN} 100$ smaller. The composites show a maximum in the pore size distribution at about $25-50 \mathrm{~nm}$,

Table 1. Lattice parameters, crystallite size and microstrain; $\mathrm{CN} 50\left(\mathrm{ZnFe}_{2} \mathrm{O}_{4}: \mathrm{g}-\mathrm{C}_{3} \mathrm{~N}_{4}=0.5\right)$, $\mathrm{CN} 75\left(\mathrm{ZnFe}_{2} \mathrm{O}_{4}: \mathrm{g}-\mathrm{C}_{3} \mathrm{~N}_{4}\right.$ $=0.75)$, and $\mathrm{CN} 100\left(\mathrm{ZnFe}_{2} \mathrm{O}_{4}: \mathrm{g}-\mathrm{C}_{3} \mathrm{~N}_{4}=1\right)$.

\begin{tabular}{lccccc}
\hline Sample & Unit cell, $\AA$ & Crystallite size, $\mathbf{n m}$ & Microstrain, \% & $\mathbf{R}_{\text {wp }}$, \% & $\chi^{\mathbf{2}}$ \\
\hline $\mathrm{CN} 50$ & $8.4312 \pm 0.0007$ & $8 \pm 0.2$ & 1.77 & 9.1 & 1.74 \\
$\mathrm{CN75}$ & $8.4321 \pm 0.0005$ & $9 \pm 0.4$ & 1.47 & 8.4 & 1.71 \\
$\mathrm{CN100}$ & $8.4325 \pm 0.0003$ & $11 \pm 0.4$ & 1.16 & 7.9 & 1.68 \\
$\mathrm{ZnFe}_{2} \mathrm{O}_{4}$ & $8.4342 \pm 0.0002$ & $23 \pm 0.3$ & 0.53 & 7.2 & 1.53 \\
\hline
\end{tabular}

Table 2. Textural characteristics of the samples studied.

\begin{tabular}{|c|c|c|c|}
\hline Sample & $\begin{array}{l}\text { Specific surface } \\
\text { area, } S_{\text {BET }}, m^{2} g^{-1}\end{array}$ & $\begin{array}{l}\text { Total pore volume, } \\
\quad V_{\text {total }}, \mathrm{cm}^{3} \mathrm{~g}^{-1}\end{array}$ & $\begin{array}{c}\text { Average pore size, } \\
D_{\text {average }}, \mathrm{nm}\end{array}$ \\
\hline $\mathrm{g}-\mathrm{C}_{3} \mathrm{~N}_{4}$ & 88 & 0.47 & 22 \\
\hline $\mathrm{ZnFe}_{2} \mathrm{O}_{4}$ & 34 & 0.27 & 32 \\
\hline CN50 & 72 & 0.44 & 25 \\
\hline CN75 & 77 & 0.44 & 23 \\
\hline CN100 & 67 & 0.23 & 14 \\
\hline
\end{tabular}

Tsvetkov et al.: Visible Light-Driven Photocatalytic Activity ... 

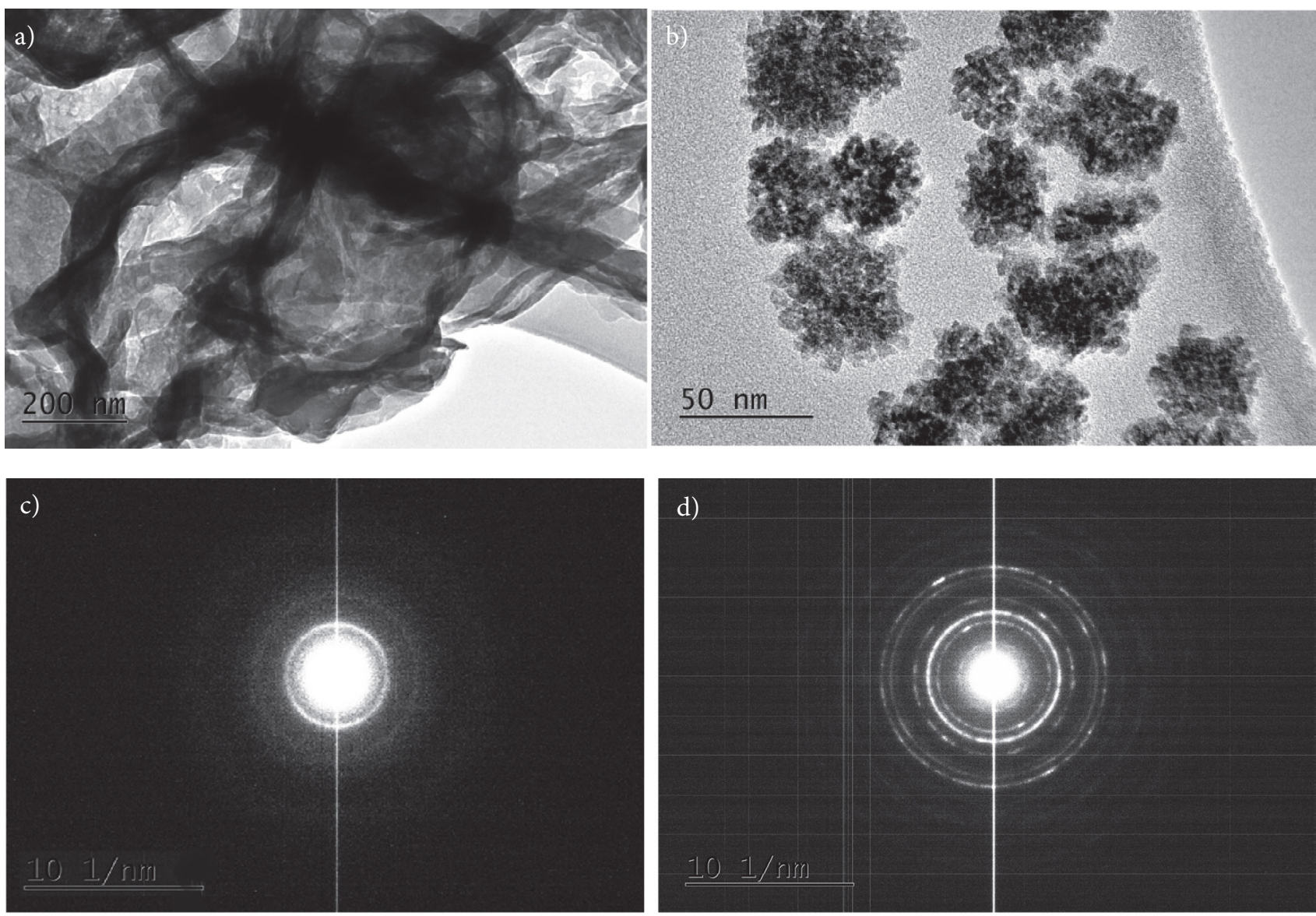

e)

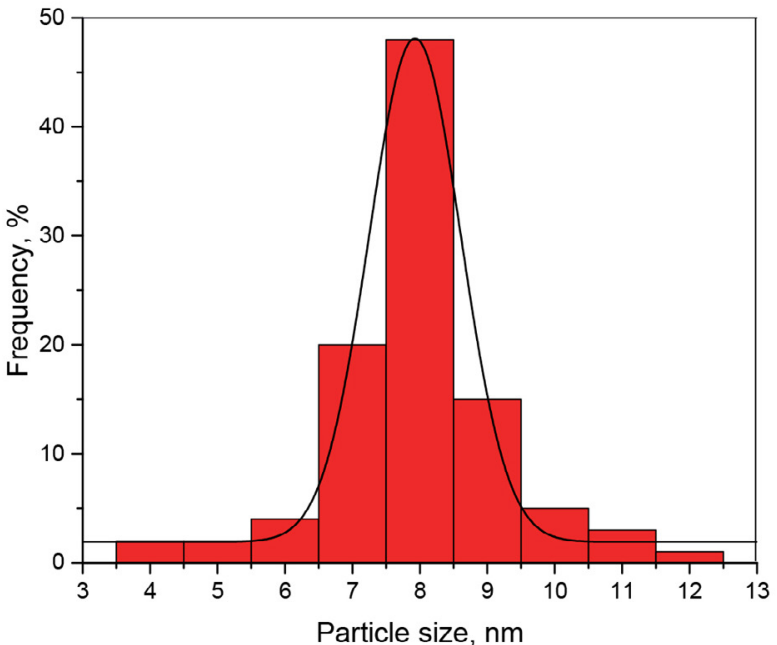

Figure 3. TEM micrographs of (a) g- $\mathrm{C}_{3} \mathrm{~N}_{4}$ and (b) CN50 presented along with the electron diffraction (c) and (d), respectively. The particles size distribution for CN50 is shown in (e).

while $\mathrm{CN} 100$ shows a broad polydispersed pore size distribution (Fig. 4, b).

The pure $\mathrm{g}-\mathrm{C}_{3} \mathrm{~N}_{4}$ sample has the largest specific surface area, $88 \mathrm{~m}^{2} \mathrm{~g}^{-1}$, while pure $\mathrm{ZnFe}_{2} \mathrm{O}_{4}$ with $34 \mathrm{~m}^{2} \mathrm{~g}^{-1}$ has the lowest one among the samples tested (Table 2). In spite of the statement that $\mathrm{g}-\mathrm{C}_{3} \mathrm{~N}_{4}$ exhibits low $\mathrm{S}_{\mathrm{BET}},{ }^{42} 88 \mathrm{~m}^{2} \mathrm{~g}^{-1}$ is a reasonably good value, comparing for example with
$9.6 \mathrm{~m}^{2} \mathrm{~g}^{-1}$ reported in ref. ${ }^{42}$ for $\mathrm{g}-\mathrm{C}_{3} \mathrm{~N}_{4}$ obtained by the same hydrothermal method for $48 \mathrm{~h} / 180^{\circ} \mathrm{C}\left(12 \mathrm{~h} / 180^{\circ} \mathrm{C}\right.$ in present work). Apparently, the duration of the hydrothermal treatment is influencing the agglomeration of the sample. The addition of $\mathrm{rGO}$ and $\mathrm{ZnFe}_{2} \mathrm{O}_{4}$ caused a reduction of the specific surface area leading to composites with 77,72 , and $67 \mathrm{~m}^{2} \mathrm{~g}^{-1}$ surface area, which could be due to 

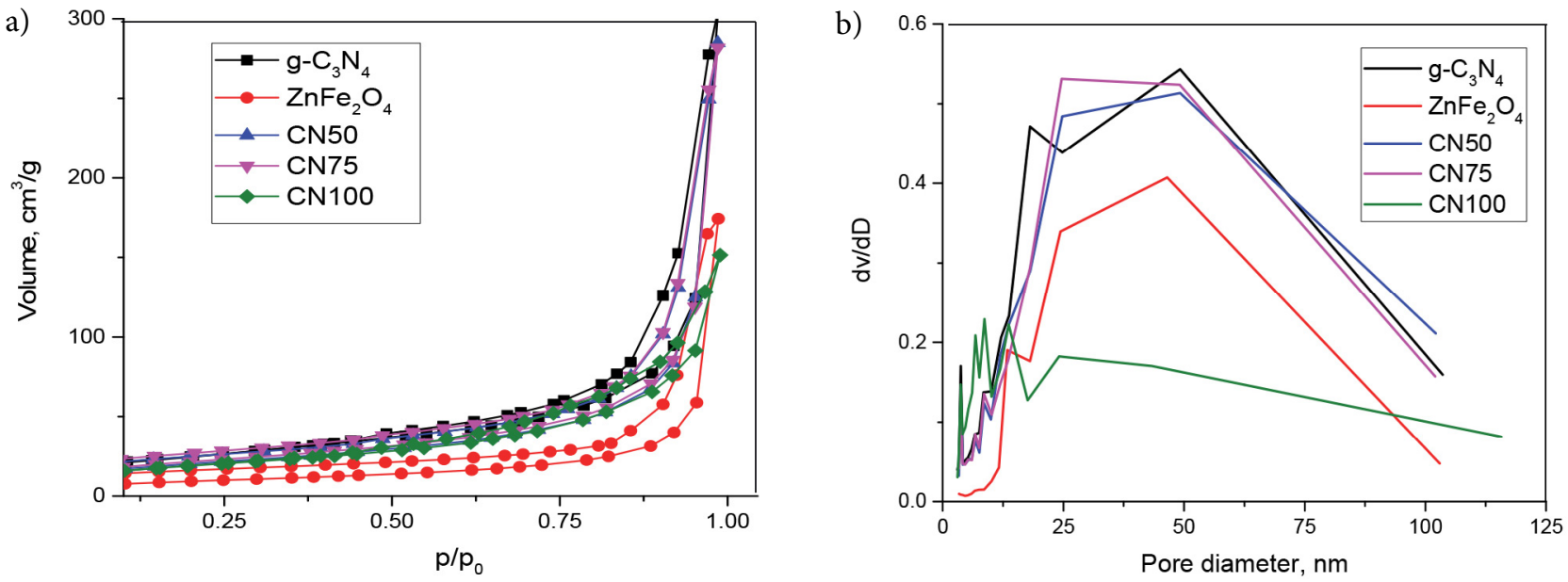

Figure 4. Adsorption-desorption isotherms of the pure g- $\mathrm{C}_{3} \mathrm{~N}_{4}$ and $\mathrm{ZnFe}_{2} \mathrm{O}_{4}$, and the composites $\mathrm{CN} 50, \mathrm{CN} 75, \mathrm{CN} 100$ (a) and $\mathrm{BJH}$ pore diameter distribution, determined from the desorption branch of the isotherm (b); $\mathrm{V}$ - pore volume, $\mathrm{D}$ - pore diameter.

their deposition on the pores of carbon nitride. Quite likely the presence of $g-\mathrm{C}_{3} \mathrm{~N}_{4}$ inhibits the agglomeration of $\mathrm{ZnFe}_{2} \mathrm{O}_{4}$ particles and makes them uniformly dispersed.

\section{2. Optical and Photocatalytic Properties}

\section{2. 1. Optical Properties}

The UV/Vis spectra of $\mathrm{g}_{-} \mathrm{C}_{3} \mathrm{~N}_{4}, \mathrm{ZnFe}_{2} \mathrm{O}_{4}$ and the composites are presented in Fig. 5, a, clearly showing enhanced light absorption of the composites, probably due to interfacial interaction between $\mathrm{g}-\mathrm{C}_{3} \mathrm{~N}_{4}$ and $\mathrm{ZnFe}_{2} \mathrm{O}_{4} \cdot{ }^{43}$ It can be expected that the enhanced light absorption could lead to higher photocatalytic activity by generating more photoinduced charge carriers under visible light. Based on these UV/Vis spectra, the band gap energy was calculated for all the samples (Fig. 5, b). The values for the similar band gaps of the composites with energy of $2.30-2.31 \mathrm{eV}$ (538-536 nm), between the values of $\mathrm{g}-\mathrm{C}_{3} \mathrm{~N}_{4}, 2.7 \mathrm{eV}(458$

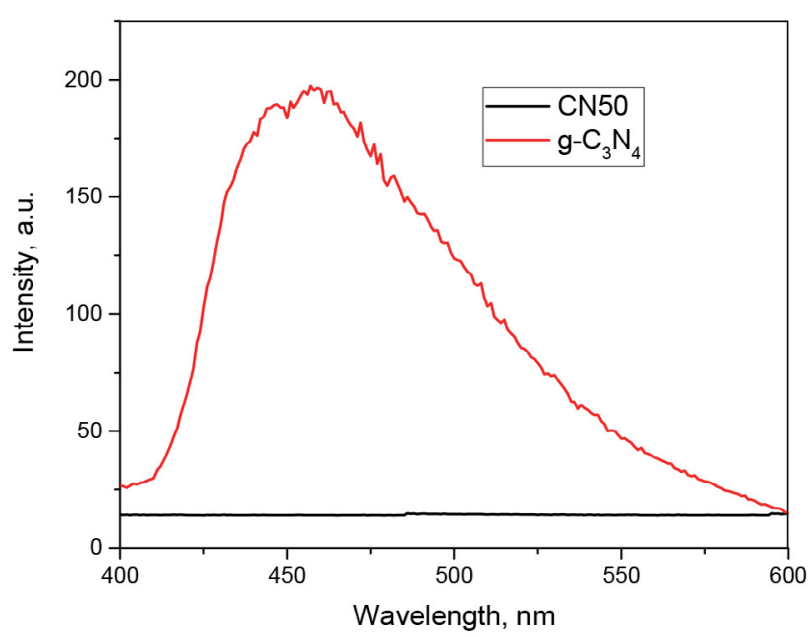

Figure 6. Typical photoluminescence of $\mathrm{g}-\mathrm{C}_{3} \mathrm{~N}_{4}$, compared with the absence for CN50.
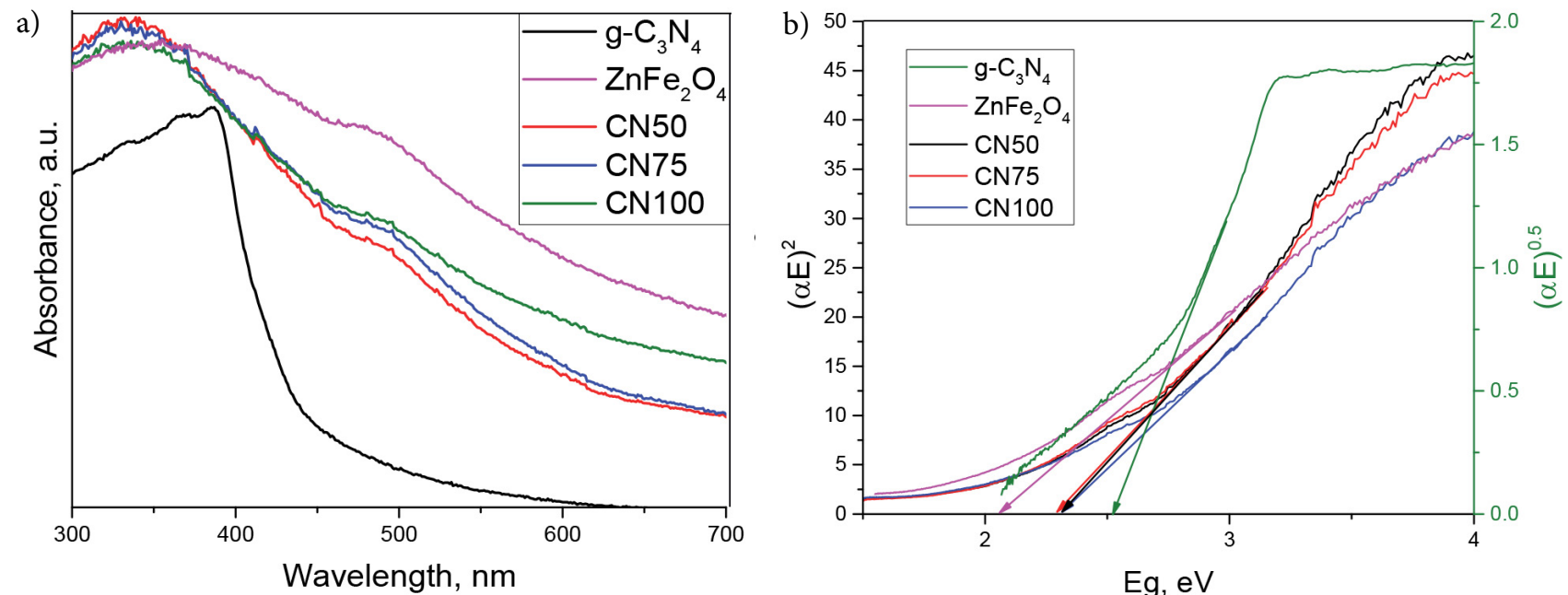

Figure 5. (a) UV/Vis spectra and (b) the energy of the forbidden zone, $E_{g}$, for all the samples studied 
$\mathrm{nm})$ and $\mathrm{ZnFe}_{2} \mathrm{O}_{4}, 2.06 \mathrm{eV}(600 \mathrm{~nm})$, confirm their prospective for photocatalytic activity higher than that of g- $\mathrm{C}_{3} \mathrm{~N}_{4}$.

Such a prospective is also indicated by the absence of fluorescence in the composites, which provides evidence for efficient inhibition of radiative recombination of photogenerated $\mathrm{e}^{-} / \mathrm{h}^{+}$(Fig. 6). The strong fluorescence of the pure $\mathrm{g}-\mathrm{C}_{3} \mathrm{~N}_{4}$ related to strong $\mathrm{e}^{-} / \mathrm{h}^{+}$recombination (Fig. 6), may explain the low photocatalytic activity of the pristine sample.

\section{2. 2. Degradation of Malachite Green Under Visible Light Irradiation}

The photocatalytic performance of the samples for degradation of malachite green under visible light illumination is shown in Fig. 7. In the given range of reaction conditions, adsorption of malachite green on the catalyst surface cannot be neglected (Table 3). However, this was well considered in the subsequent interpretation of collected experimental data. The relevant data for the rate constants are summarized in Table 3.

The rate constant obtained for the photolysis was 0.6 $\times 10^{-3} \mathrm{~min}^{-1}$. The pure samples $\mathrm{g}_{-} \mathrm{C}_{3} \mathrm{~N}_{4}$ and $\mathrm{ZnFe}_{2} \mathrm{O}_{4}$

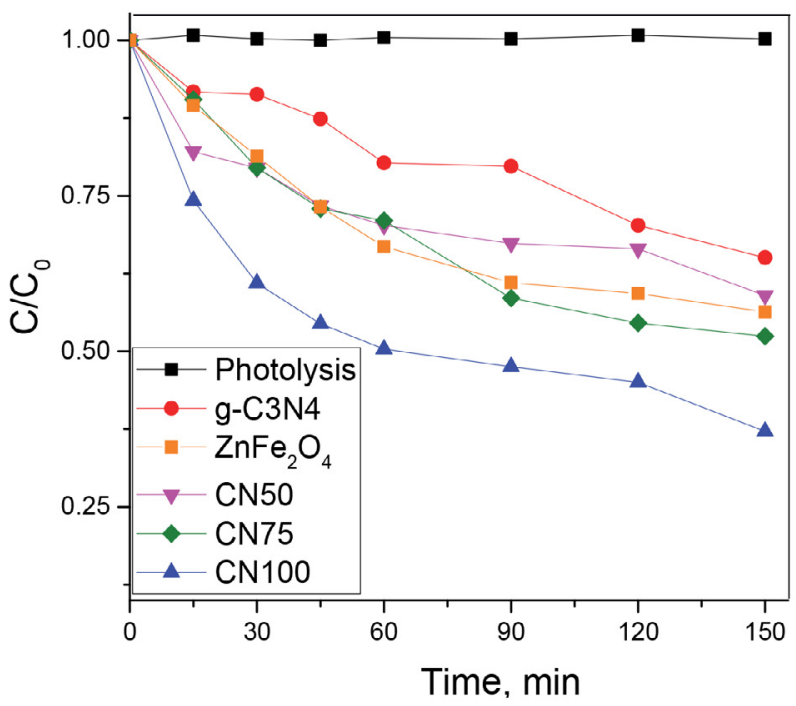

Figure 7. Photocatalytic performance of as-prepared samples for degradation of malachite green under visible-light illumination. showed low values for their rate constants: 2.9 and $4.6 \times$ $10^{-3} \mathrm{~min}^{-1}$, respectively. The rate constants of the composites were higher, and showed increasing values with increasing $\mathrm{ZnFe}_{2} \mathrm{O}_{4} / \mathrm{g}-\mathrm{C}_{3} \mathrm{~N}_{4}$ ratio $(0.5,0.75,1)$, i.e. $4.0 \times 10^{-3}$, $5.1 \times 10^{-3}$ and $7.7 \times 10^{-3} \mathrm{~min}^{-1}$, respectively. Apparently, $\mathrm{ZnFe}_{2} \mathrm{O}_{4}$ and $\mathrm{g}-\mathrm{C}_{3} \mathrm{~N}_{4}$ show a synergetic effect, which is best demonstrated for the composite $\mathrm{CN} 100$. The highest degradation of malachite green achieved was $63 \%$ for 150 min illumination with visible light. In Table 3 , the data for the ratio $\mathrm{k} / \mathrm{S}_{\mathrm{BET}}\left(\mathrm{min}^{-1} \mathrm{~g} \mathrm{~m}^{-2}\right)$ are presented, showing the best activity for $\mathrm{ZnFe}_{2} \mathrm{O}_{4}$, followed closely by the composite $\mathrm{CN} 100$.

The observed photocatalytic activity may be correlated to the physical properties of the catalysts, such as: (i) Surface area: the largest $S_{B E T}$ surface area of g- $C_{3} \mathrm{~N}_{4}$ among the samples tested could provide more active sites to adsorb and convert MG molecules in comparison with the $\mathrm{ZnFe}_{2} \mathrm{O}_{4}$ and the composites. However, this is not ob-

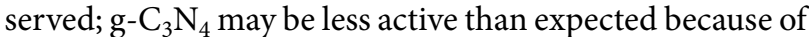
its strong $\mathrm{e}^{-} / \mathrm{h}^{+}$recombination shown by the fluorescence (Fig. 6). Among the composites, $\mathrm{CN} 100$ has less than average $S_{\mathrm{BET}}$ but showed the best photocatalytic activity. (ii) Large pore volume: it would favor the diffusion of MG molecules within the pores towards the active sites on the surface of the photocatalysts. However, g- $\mathrm{C}_{3} \mathrm{~N}_{4}$ with the largest pore volume shows the lowest activity. (iii) Pore size distribution: The composite $\mathrm{CN} 100$ has a very broad pore size distribution showing best activity i.e. positively influencing the activity (Fig. 4, b). (iv) Bandgap energy: among all samples tested, the composites have the lowest and equal value for $E_{g}$ but show different activity. Thus the band gap energy alone cannot explain all differences; the activity is determined by a combination of factors. From this it can be concluded that the most active composite CN100 has an optimum combination of band gap value, $\mathrm{ZnFe}_{2} \mathrm{O}_{4} / \mathrm{g}_{-} \mathrm{C}_{3} \mathrm{~N}_{4}$ ratio and absence of $\mathrm{e}^{-} / \mathrm{h}^{+}$recombination. The rGO, being present in equal amounts for all the composites, has the function of solid-state electron mediator, ${ }^{28,29}$ adsorbent, photosensitizer and electron acceptor. $^{28}$

For the discussion of the mechanism of the photocatalytic reaction, the values of the band edges i.e. the potentials of the current band $(\mathrm{CB})$ and the valence band (VB) of the semiconductors $\mathrm{ZnFe}_{2} \mathrm{O}_{4}$ and $\mathrm{g}-\mathrm{C}_{3} \mathrm{~N}_{4}$ should be considered. Some of the literature data are summarized

Table 3. Rate constants and extent of malachite green removal based on adsorption on the catalyst surface and degradation.

\begin{tabular}{|c|c|c|c|c|}
\hline Sample & $\begin{array}{l}\text { Rate constant, } \\
\times 10^{-3} \mathrm{~min}^{-1}\end{array}$ & $\begin{array}{l}\text { Rate constant to } S_{\mathrm{BET}} \\
\quad \times 10^{-4}, \mathrm{~min}^{-1} \mathrm{~g} \mathrm{~m}^{-2}\end{array}$ & $\begin{array}{c}\text { Adsorption, } \\
\%\end{array}$ & $\begin{array}{c}\text { Degradation after } 150 \mathrm{~min} \text {, } \\
\%\end{array}$ \\
\hline $\mathrm{g}-\mathrm{C}_{3} \mathrm{~N}_{4}$ & 2.9 & 0.395 & 47 & 35 \\
\hline $\mathrm{ZnFe}_{2} \mathrm{O}_{4}$ & 4.6 & 1.353 & 63 & 44 \\
\hline CN50 & 4.0 & 0.556 & 76 & 41 \\
\hline CN75 & 5.1 & 0.66 & 78 & 48 \\
\hline $\mathrm{CN} 100$ & 7.7 & 1.149 & 86 & 63 \\
\hline
\end{tabular}

Tsvetkov et al.: Visible Light-Driven Photocatalytic Activity ... 
Table 4. Potentials of current band (CB) and valence band (VB) of $\mathrm{ZnFe}_{2} \mathrm{O}_{4}$ and $\mathrm{g}-\mathrm{C}_{3} \mathrm{~N}_{4}$.

\begin{tabular}{cccccccc}
\hline № & $\begin{array}{c}\mathbf{C B}, \\
\mathbf{e V}\end{array}$ & $\begin{array}{c}\mathrm{ZnFe}_{2} \mathbf{O}_{4} \\
\mathbf{V B} \\
\mathbf{e V}\end{array}$ & $\begin{array}{c}\boldsymbol{E}_{\boldsymbol{g}} \\
\mathbf{e V}\end{array}$ & $\begin{array}{c}\mathbf{C B}, \\
\mathbf{e V}\end{array}$ & $\begin{array}{c}\mathbf{g}_{\mathbf{3}} \mathbf{N}_{\mathbf{4}} \\
\mathbf{V B} \\
\mathbf{e V}\end{array}$ & $\begin{array}{c}\boldsymbol{E}_{\boldsymbol{g}} \\
\mathbf{e V}\end{array}$ & Ref. \\
\hline 1 & 0.29 & 2.35 & 2.06 & -1.08 & 1.54 & 2.62 & Present work \\
2 & 0.41 & 2.38 & 1.97 & - & - & - & 45 \\
3 & -0.06 & 1.8 & 1.76 & -1.03 & 1.64 & 2.67 & 42 \\
4 & -1.54 & 0.38 & 1.92 & -1.26 & 1.34 & 2.60 & 40 \\
5 & - & - & - & - & 1.54 & - & 43 \\
\hline
\end{tabular}

and presented in Table 4 along with data from our study. It can be seen that in the literature for $\mathrm{g}-\mathrm{C}_{3} \mathrm{~N}_{4}$ similar values were reported, i.e. $\mathrm{CB}-1.03$ and $\mathrm{VB} 1.64 \mathrm{eV}^{44}$ as well as -1.26 and $1.34 \mathrm{eV}^{42}$. This is in good agreement with the value for the $\mathrm{VB}$ of $\mathrm{g}-\mathrm{C}_{3} \mathrm{~N}_{4}(1.54 \mathrm{eV})$ determined by $\mathrm{X}$-ray photoelectron spectroscopy. ${ }^{45}$ The literature data for $\mathrm{Zn}$ $\mathrm{Fe}_{2} \mathrm{O}_{4}$ are less consistent: values observed include -0.06 and $1.8 \mathrm{eV}^{44}$ as well as $-1.54 \mathrm{eV}$ and $0.38 \mathrm{eV}^{42}$ Taking into account the literature data for the current and valence band it should be mentioned that the $\mathrm{CB}$ and $\mathrm{VB}$ values for $\mathrm{ZnFe}_{2} \mathrm{O}_{4}$ are lying over those for $\mathrm{g}-\mathrm{C}_{3} \mathrm{~N}_{4}$ according to ref. ${ }^{44}$ but under values of g- $\mathrm{C}_{3} \mathrm{~N}_{4}$ according to ref. ${ }^{42}$ i.e. inconsistency in the data is observed. This can lead to a different way of the interpretation of energy transfer during the photocatalytic process, particularly the migration of electrons and holes between the current band and the valence band of the semiconductors $\mathrm{ZnFe}_{2} \mathrm{O}_{4}$ and g- $\mathrm{C}_{3} \mathrm{~N}_{4}$.

For the samples synthesized $\mathrm{ZnFe}_{2} \mathrm{O}_{4}$ and g- $\mathrm{C}_{3} \mathrm{~N}_{4}$ the band edge positions were evaluated applying the simple equations $E_{V B}=X-E_{0}+0.5 E_{g}$ and $E_{C B}=E_{V B}-E_{g}$. The symbols used $E_{C B}, E_{V B}$, and $X$ are showing the potentials of the conduction band, of the valence band and the electronegativity of the semiconductors $\mathrm{ZnFe}_{2} \mathrm{O}_{4}$ or g- $\mathrm{C}_{3} \mathrm{~N}_{4}$ defined as the geometric average of the absolute electronegativity of the constituent atoms. ${ }^{46}$ According the literature data the energy of the free electrons on the hydrogen scale $E_{0}$ is about $4.5 \mathrm{eV}^{46}$ For the semiconductors $\mathrm{ZnFe}_{2} \mathrm{O}_{4}$ and g- $\mathrm{C}_{3} \mathrm{~N}_{4}$ the $X$ values were calculated to be 5.82 and $4.73 \mathrm{eV}$, respectively. Following this, the bottom of current band and the top of valence band were calculated to be $-1.08 \mathrm{eV}$ and $1.54 \mathrm{eV}$ for $\mathrm{g}_{-} \mathrm{C}_{3} \mathrm{~N}_{4}$, and $0.29 \mathrm{eV}$ and $2.35 \mathrm{eV}$ for $\mathrm{Zn}$ $\mathrm{Fe}_{2} \mathrm{O}_{4}$, respectively (Table 4). The data for $\mathrm{ZnFe}_{2} \mathrm{O}_{4}$ are in good agreement with data in ref. ${ }^{47}$ in spite of the different synthetic method used, influencing the value.

Based on these results, a mechanism for photodegradation of MG over $\mathrm{ZnFe}_{2} \mathrm{O}_{4} / \mathrm{r}-\mathrm{GO} / \mathrm{g}-\mathrm{C}_{3} \mathrm{~N}_{4}$ composites can be proposed (Fig. 8). When $\mathrm{ZnFe}_{2} \mathrm{O}_{4} / \mathrm{r}-\mathrm{GO} / \mathrm{g}-\mathrm{C}_{3} \mathrm{~N}_{4}$ composites are exposed to visible light, both $\mathrm{ZnFe}_{2} \mathrm{O}_{4}$ and g- $\mathrm{C}_{3} \mathrm{~N}_{4}$ are excited. The photogenerated holes and electrons are in the valence band and conduction band, respectively. g- $\mathrm{C}_{3} \mathrm{~N}_{4}$ can effectively absorb visible light to form photoexcited charge carriers.

Because the current band of $\mathrm{g}-\mathrm{C}_{3} \mathrm{~N}_{4}$ is more negative than that of $\mathrm{ZnFe}_{2} \mathrm{O}_{4}$, the electrons migrate into the current

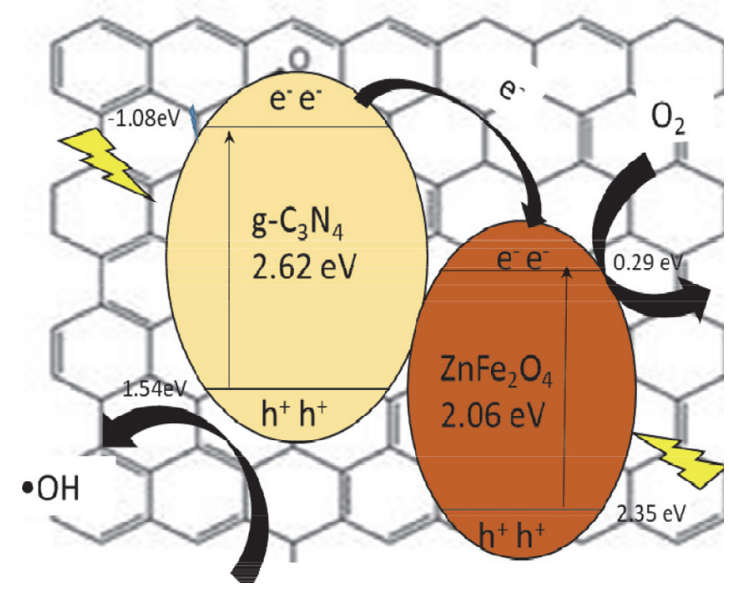

Figure 8. Illustration of the mechanism of the photocatalytic activity of as prepared $\mathrm{ZnFe}_{2} \mathrm{O}_{4} / \mathrm{GO} / \mathrm{g}-\mathrm{C}_{3} \mathrm{~N}_{4}$ samples.

band of $\mathrm{ZnFe}_{2} \mathrm{O}_{4}$; holes in the valence band of $\mathrm{ZnFe}_{2} \mathrm{O}_{4}$ simultaneously migrate to the $\mathrm{VB}$ of $\mathrm{g}-\mathrm{C}_{3} \mathrm{~N}_{4}$. By this the photogenerated electrons are accumulated on $\mathrm{ZnFe}_{2} \mathrm{O}_{4}$ and holes accumulated on $\mathrm{g}_{-} \mathrm{C}_{3} \mathrm{~N}_{4}$. This in turn with water-dissolved oxygen and adsorbed water molecules causes the formation of radicals. These are well known as oxidizing species and as a result MG degradation takes place. The rGO is improving the photocatalytic properties of the composites obtained by efficient separation of photo-induced charges. ${ }^{23}$

\section{Conclusions}

Nanocomposites of the type $\mathrm{ZnFe}_{2} \mathrm{O}_{4} / \mathrm{r}-\mathrm{GO} / \mathrm{g}-\mathrm{C}_{3} \mathrm{~N}_{4}$, based on coupling of two semiconductors, were successfully prepared by applying solvothermal synthesis, where ethylene glycol was used as a solvent. All of the composites, including the stand alone components, were tested and showed activity for photocatalytic degradation of malachite green in aqueous solution under visible light irradiation. The composites show better activity than the pristine $\mathrm{g}_{-} \mathrm{C}_{3} \mathrm{~N}_{4}$ and $\mathrm{ZnFe}_{2} \mathrm{O}_{4}$, with the $\mathrm{CN} 100$ sample in which $\mathrm{g}-\mathrm{C}_{3} \mathrm{~N}_{4}$ and $\mathrm{ZnFe}_{2} \mathrm{O}_{4}$ were present in equal amount showing the highest activity. The improved photocatalytic activity was due to the synergy and the charge transfer between $\mathrm{g}^{-} \mathrm{C}_{3} \mathrm{~N}_{4}$ and $\mathrm{ZnFe}_{2} \mathrm{O}_{4}$ as well as the efficient separa- 
tion of photo-induced charges by rGO. More research has to be done to find the optimum $\mathrm{ZnFe}_{2} \mathrm{O}_{4} / \mathrm{g}-\mathrm{C}_{3} \mathrm{~N}_{4}$ ratio. The examined composites show potential for degradation of water-dissolved organic pollutants.

\section{Acknowledgements.}

M.T. acknowledges the financial support from the program "Young scientists and Postdoctoral candidates" of the Bulgarian Ministry of Education and Science, MCD № 577/2018. The textural measurements were done in Prof. Albin Pintar's Laboratory, National Institute for Chemistry, Slovenia.

\section{References}

1. J. Longbo, Y. Xingzhong, P. Yang, L. Jie, Z. Guangming, W. Zhibin, W. Hou, Appl. Catal. B-Environ. 2017, 217, 388-406.

2. E. Sudova, J. Machova, Z. Svobodova, T. Vesely, Veterinarni Med. 2007, 52, 527-539. DOI:10.17221/2027-VETMED

3. N. J. Karrer, G. Ryhiner, E. Heinzle, Water Res. 1997, 31, 1013-1020. DOI:10.1016/S0043-1354(96)00356-9

4. L. Ying-yu, L. Lin, L. Xiao-yan, J. Clean. Prod. 2020, 244, 118705. DOI:10.1016/j.jclepro.2019.118705

5. L. Boutilier, R. Jamieson, R. Gordon, C. Lake, W. Harte, Water Res. 2009, 43, 4370-4380. DOI:10.1016/j.watres.2009.06.039

6. S. Bhattacharjee, S. Datta, C. Bhattacharjee, Desalination 2007, 212, 92-102. DOI:10.1016/j.desal.2006.08.014

7. X. Zi-Peng, S. De-Zhi, J. Hazard. Mater. 2009, 168, 1264-1268. DOI:10.1016/j.jhazmat.2009.03.008

8. S. Zodi, O. Potier, F. Lapicque, J.-P. Leclerc, Desalination 2010, 261, 186-190. DOI:10.1016/j.desal.2010.04.024

9. S. S. Mansouri, I. A. Udugama, A. Mitic, A. Rubin, L. Rudolfsson, K. V. Gernaey, Comput. Aided Chem. Eng. 2017, 40, 391-396. DOI:10.1016/B978-0-444-63965-3.50067-2

10. A. F. S. Foureaux, E. O. Reis, Y. Lebron, V. Moreira, L. V. Santos, M. S. Amaral, L. C. Lange, Sep. Purif. Technol. 2019, 212, 171-179. DOI:10.1016/j.seppur.2018.11.018

11. W. Pronk, A. Ding, E. Morgenroth, N. Derlon, P. Desmond, M. Burkhardt, B. Wu, A. G. Fane, Water Res. 2019, 149, 553565. DOI:10.1016/j.watres.2018.11.062

12. R. Bochenek, R. Sitarz, D. Antos, Chem. Eng. Sci. 2011, 66, 6209-6219. DOI:10.1016/j.ces.2011.08.046

13. C. Guillard, H. Lachheb, A. Houas, M. Ksibi, E. Elaloui, J. M. Hermann. J. Photochem. Photobiol. A Chem. 2003, 158, 27-36. DOI:10.1016/S1010-6030(03)00016-9

14. R. Kralchevska, M. Milanova, M. Tsvetkov, D. Dimitrov, D. Todorovsky, J. Mater. Sci. 2012, 47, 4936-4945.

DOI:10.1007/s10853-012-6368-4

15. R. Kralchevska, M. Milanova, D. Hristov, A. Pintar, D. Todorovsky, Mater. Res. Bull. 2012, 47, 2165-2177.

DOI:10.1016/j.materresbull.2012.06.009

16. R. Kralchevska, M. Milanova, P. Kovacheva, J. Kolev, G. Avdeev, D. Todorovsky, Cent. Eur. J. Chem. 2011, 9, 10271038. DOI:10.2478/s11532-011-0089-4
17. M. Uzunova-Bujnova, R. Kralchevska, M. Milanova, R. Todorovska, D. Hristov, D. Todorovsky, Catal. Today 2010, 151, 14-20. DOI:10.1016/j.cattod.2010.02.058

18. M. Uzunova-Bujnova, R. Todorovska, M. Milanova, R. Kralchevska, D. Todorovsky, Appl. Surf. Sci. 2009, 256, 830-837. DOI:10.1016/j.apsusc.2009.08.069

19. G. Dong, Y. Zhang, Q. Pan, J. Qiu, J. Photochem. Photobiol. C Photochem. Reviews 2014, 20, 33-50.

20. X. Wang, K. Maeda, A.Thomas, K. Takanabe, G. Xin, J. M. Carlsson, K. Domen, M. Antonietti, Nat. Mater. 2009, 8, 7680. DOI: $10.1038 / \mathrm{nmat} 2317$

21. J. Wen, J. Xie, X. Chen, X. Li, Appl. Surf. Sci. 2017, 391, 72123. DOI:10.1016/j.apsusc.2016.07.030

22. L. Shi, F. Wang, J. Zhang, J. Sun, Ceram. Int. 2016, 42, 1811618123. DOI:10.1016/j.ceramint.2016.08.124

23. V. S. Amrutha, K. S. Anantharaju, D. S. Prasanna, Arabian J. Chem. 2017, 10 DOI:10.1016/j.arabjc.2017.11.016

24. K. Woan, G. Pyrgiotakis, W. Sigmund, Adv. Mater. 2009, 21, 2233-2239. DOI:10.1002/adma.200802738

25. Q. Ming, S. Qin, W. Guanglei, Zh. Bohan, W. Zhengdong, W. Hongjing, Mater. Sci. Eng. B 2017, 224, 125-138.

DOI:10.1016/j.mseb.2017.07.016

26. X. Xuejun, S. Zhichun, L. Liping, W. Zehao, C. Ze, R. Rui, H. Yonghong, W. Duan, Appl. Surf. Sci. 2018, 435, 1296-1306.

27. M. Huang, J. Yu, Q. Hu, W. Su, M. Fan, B. Li, L. Dong, Appl. Surf. Sci. 2016, 389, 1084-1093.

DOI:10.1016/j.apsusc.2016.07.180

28. F. Wu, X. Li, W. Liu, S. Zhang, Appl. Surf. Sci. 2017, 405, 6070. DOI:10.1016/j.apsusc.2017.01.285

29. G. Zhao, X. Huang, F. Fin, G. Zhang, J. T. S. Irvine, Catal. Sci. Technol. 2015, 6, 3416-3422.

DOI:10.1039/C5CY00379B

30. W. S. Hummers, R. E. Offeman, J. Am. Chem. Soc. 1958, 806, 1339-1339. DOI:10.1021/ja01539a017

31. M. Tsvetkov, M. Milanova, L. C. J. Pereira, J. C. Waerenborgh, Z. Cherkezova-Zheleva, J. Zaharieva, I. Mitov, Chem. Papers, 2016, 70, 1600-1610.

32. J. Rodriguez-Carvajal, Newsletter, 2001, 26, 12-19.

33. J. Tauc, R. Grigorovici, A. Vancu, Phys. Status Solidi 1966, 15, 627-637. DOI:10.1002/pssb.19660150224

34. C. A. Schneider, W. S. Rasband, K. W. Eliceiri, Nature methods, 2012, 9, 671-675, PMID 22930834.

DOI: $10.1038 /$ nmeth.2089

35. M. Tzvetkov, M. Milanova, Z. Cherkezova-Zheleva, I. Spassova, E. Valcheva, J. Zaharieva, I. Mitov, Acta Chim. Slov. 2017, 64, 299-311. DOI:10.17344/acsi.2016.3049

36. K. Zaharieva, V. Rives, M. Tsvetkov, Z. Cherkezova-Zheleva, B. Kunev, R. Trujillano, I. Mitov, M. Milanova, Mater. Chem. Phys. 2015, 160, 271-278.

DOI:10.1016/j.matchemphys.2015.04.036

37. G. Tzvetkov, M. Tsvetkov, T. Spassov, Superlattice Microst. 2018, 119, 122-133. DOI:10.1016/j.spmi.2018.04.048

38. I. N. Leontyev, A. B. Kuriganova, M. Allix, A. Rakhmatullin, P. E. Timoshenko, O. A. Maslova, A. S. Mikheykin, N. V. Smirnova, Phys. Status Solidi B 2018, 1800240.

DOI:10.1002/pssb.201800240 
39. W. L. Smith, J. Appl. Crystalography 1972, 5, 127-130. DOI:10.1107/S0021889872008921

40. K. S. W. Sing, D. H. Everett, R. A. W. Haul, L. Moscou, R. A. Pierotti, J. Rouquerol, T. Siemieniewska, Pure Appl. Chem. 1985, 57, 603-604.

41. J. G. Yu, Q. J. Xiang, M. H. Zhou, Appl. Catal. B-Environ. 2009, 90, 595-602. DOI:10.1016/j.apcatb.2009.04.021

42. L. Chen, W. Ma, J. Dai, J. Zhao, C. Li, Y. Yan, J. Photochem. Photobiol. A 2016, 328, 24-32.

DOI:10.1016/j.jphotochem.2016.04.026

43. S. Borthakur, L. Saikia, J. Environ. Chem. Eng. 2019, 7, 103035.

DOI:10.1016/j.jece.2019.103035
44. S. Patnaik, K. K. Das, A. Mohanty, K. Parida, Catal. Today, 2018, 315, 52-66. DOI:10.1016/j.cattod.2018.04.008

45. W. Hu, J. Yu, X. Jiang, X. Liu, R. Jin, Y. Lu, L. Zhao, Y. Wu, Y. He, Colloids Surf. A Physicochem. Eng. Asp. 2017, 514, 98-106. DOI:10.1016/j.colsurfa.2016.11.058

46. R. Beranek, Adv. Phys. Chem. 2011, 2011, ID 786759, 20 pages, DOI:10.1155/2011/786759

47. L. Jing, Y. Xu, C. Qin, J. Liu, S. Huang, M. He, H. Xu, H. Li, Mater. Res. Bull. 2017, 95, 607-615.

DOI:10.1016/j.materresbull.2017.06.003

\section{Povzetek}

Nanokompozitni fotokatalizatorji $\mathrm{ZnFe}_{2} \mathrm{O}_{4} / \mathrm{rGO} / \mathrm{g}-\mathrm{C}_{3} \mathrm{~N}_{4} \mathrm{z}$ različnimi masnimi razmerji $\mathrm{ZnFe}_{2} \mathrm{O}_{4} / g-\mathrm{C}_{3} \mathrm{~N}_{4}(0,5 ; 0,75 ; 1)$ so bili pripravljeni $\mathrm{z}$ večstopnejsko solvotermalno metodo ter uporabo etilen glikola kot topila. Za karakterizacijo kompozitov so bile uporabljene različne metode, kot so rentgenska difrakcija, UV-Vis spektroskopija in fotoluminiscenčna spektroskopija. Nastanek mezo-/makroporozne strukture s specifično površino med $67 \mathrm{in} 77 \mathrm{~m}^{2} \mathrm{~g}^{-1}$ je bil potrjen $\mathrm{z}$ adsorpcijo/desorpcijo $\mathrm{N}_{2}$. Ugotovljeno je bilo, da je v primerjavi z g- $\mathrm{C}_{3} \mathrm{~N}_{4}(2,7 \mathrm{eV})$ širina prepovedanega pasu kompozitov manjša $(2,30 \mathrm{eV})$. V nasprotju s g- $\mathrm{C}_{3} \mathrm{~N}_{4}$, kompoziti niso izkazovali fluorescence, torej ni prišlo do rekombinacije $\mathrm{e}^{-} / \mathrm{h}^{+}$. Vsi vzorci, vključno s g- $\mathrm{C}_{3} \mathrm{~N}_{4}$ in $\mathrm{ZnFe}_{2} \mathrm{O}_{4}$, so bili testirani za adsorpcijo in fotokatalitično razgradnjo vodnih raztopin zelenega malahita $\left(10^{-5} \mathrm{M}\right)$ pri obvsevanju $\mathrm{z}$ vidno svetlobo $(\lambda>400 \mathrm{~nm})$. Rezultati kažejo, da imajo pripravljeni nanokompoziti večjo absorpcijo in fotokatalitično aktivnost kot nemodificirana g- $\mathrm{C}_{3} \mathrm{~N}_{4}$ in $\mathrm{ZnFe}_{2} \mathrm{O}_{4}$ in so zato potencialni kandidati za razgradnjo organskih azobarvil v vodi.

Except when otherwise noted, articles in this journal are published under the terms and conditions of the Creative Commons Attribution 4.0 International License 